\title{
КОГНИТИВНЫЙ ПОДХОД К ИССЛЕДОВАНИЮ ИМЕНИ БРЕНДА
}

В статье рассматривается феномен образования бренда с точки зрения когнитивной лингвистики. Бренд функиионирует во всех областях жизнедеятельности общества и существуюот разные точки зрения на этот феномен. С когнитивной точки зрения, бренд рассматривается как «конщептт), вбираюоиий в себя как внешние признаки (имя, слоган, логотип), так и внутренние (свойства и признаки продукты, оиящение, оченка, отномение потребителя). Конщепт - универсален по своей природе и позволяет изучать бренд во всех его взаимосвязях. Актуальность исследования состоит в том, то не вся специфика наименования брендов изучены и отсутствует едине понимание бренда в когиттивнойлингвистике.

Ключевые слова: когнитивная лингвистика, бренд, конщепт, знак, имя, значение, потребитель, проиводитель, продукт

The article examines the phenomenon of brand formation from the point of view of cognitive linguistics. The brand functions in all areas of society and there are different points of view on this phenomenon. From a cognitive point of view, a brand is viewed as a "concept" that incorporates both external features (name, slogan, logo) and internal (properties and features of products, sensation, evaluation, consumer attitude). The concept is universal in nature and allows the study of the brand in all its interrelationships. The relevance of the study lies in the fact that not all the specifics of brand names have been studied and there is no common understanding of the brand in cognitive linguistics.

Keywords: cognitive linguistics, brand, concept, sign, name, meaning, consumer, manufacturer, product.

В последнее время слово «бренд» активно вошел в жизнедеятельность социума. Оно является объектом рассмотрения маркетинга, а также экономики, социологии, психологии, юриспруденции и т.д. Понятие «бренд» вызывает интерес лингвистов, поскольку потребитель в первую очередь сталкивается с именем бренда. Лингвистический фокус исследования «бренда» связан в первую очередь с именем и 
идентификацией бренда (маркировочное наименование, торговая марка, нейминг). В данном случае важна когнитивная составляющая бренда, поскольку существует необходимость правильного названия продукта. Кроме того, после появления продукта на рынке, бренд начинает самостоятельное существование и прочно входит в когнитивное пространство целевой аудитории и становится частью их когнитивной картины мира [1].

Бренды занимают прочное место в сознании социума и символизируют стабильность, доверие, известность, ожидания. Поэтом считается важным исследование их семантической сущности. Семантика бренда образуется в человеческом сознании, связывает лингвистическое восприятие бренда с его смысловой функциональностью. Бренд ассоциируется в их сознании с определенными признаками, которые связаны с именем бренда. Поэтому когнитивная лингвистика нацелена на изучение бренда через его имя [2].

Бренд рассматривается с различных углов зрения: материальное/ нематериальное, функциональное/ эмоциональное, узкое/широкое. Существуют разные точки зрения на бренд. Основная сфера функционирования бренда - экономика, где этот термин рассматривается как инструмент дифференциации товара, создания конкурентоспособности и получения прибыли. Психология рассматривает бренд как образ: пучок впечатлений, оценки, суждений, мнений. В социологии бренд становится шкалой, определяющей ценностную ориентацию индивидуума и маркером социальной принадлежности. В политологии бренд является инструментом влияния на массовое сознание, атрибут авторитета и власти. В филологии и культурологи бренд выступает как символ, миф. Бренд, таким образом, рассматривается как набор символических ценностей, с одной стороны, как сервис, услуга, удовлетворяющая потребности, с другой. Бренд существует в сознании покупателя в виде лейбла, логотипа, слогана, некоего собирательного образа, обладающий аурой. Бренд включает в себя информацию о цене, упаковке, истории, репутации и т.д.[1]..

Когнитивная лингвистика рассматривает бренд как знак, концепт. Концепт, вбирающий в себя как материальные (слоган, фирменный знак, организация, товар, услуга), так и 
нематериальные (свойства продукта и впечатления) признаки. Бренд, в отличие от других концептов культуры, создается искусственно и осознано производителем. Лингвисты считают бренд нечто промежуточным, между именем нарицательным и собственным, если это не связано с известной личностью (политиком, спортсменом, артистом) и его именем [4].

С лингвокогнитивной позиции бренд предстает как многомерное явление. Знак обладает лингвистическими и прагматическими значениями, т.е. включает в себя как понятийный, так и ценностный компонент. Лексическое значение имени бренда предметно соотнесено. Прагматическое состоит из эмоциональной, оценочной, социальной, психологической, культурологической, исторической коннотации. Особенность бренда в том, что в нем осознанно заложена некая хорошо продуманная первоначальная концепция разработчика. Затем бренд обретает другие компоненты значения, после соприкосновения бренда и его потребителя. Оба компонента значения функционируют в когнитивном пространстве потребителей, определяя тем самым его многомерность [3].

Исходя из многокомпонентности бренда, когнитивная лингвистика исследует его через призму «концепта». Концепт абстрактен, позволяет отвлекаться от мелочей, таким образом, обладает заместительной функцией, позволяет охватить значение во всех его аспектах. Концепт зависит от культурного опыта человека. Изучение бренда с культурологической точки зрения, выводит на первый план его ценностное значение. При этом, следует отметить, что положительная оценка бренда является доминирующей, поскольку изначально заложена производителем.

Бренд в нашей работе рассматривается как искусственно созданный концепт. Появление бренда в первую очередь связано с формированием его имени. Имя бренда в первую очередь отражает основные характеристики продаваемого продукта или сервиса. Понятийные признаки бренда идентифицируют его, выделяют среди множества подобных товаров на рынке. Как правило, над именем бренда работает целый ряд специалистов из разных сфер. В лингвистике существует новый термин, обозначающий процесс наименования бренда - нейминг. Бренднейм - продукт творческого, научного, технологического усилия. 
На современном рынке существует много конкурирующих производителей, продающих одинаковые товары. В таких условиях маркетолгам и разработчикам бренда трудно привлечь внимание потребителя, заинтересовать его, и вызвать желание купить именно этот товар. Прибыль в условиях конкуренции зависит от удачно подобранного имени бренда.

В процессе имяобразования бренда во внимание берутся многие компоненты: лингвистические, фонетические, семантические, психологические, культурные. Лингвистическая часть бренда является наиболее видимой и ощутимой, связывает продукт с его потребителем. Имя бренда идентифицирует производителя, товар, сервис, услугу. При его создании берутся во внимание многие стороны слова.

Имя должно:

1. легко произноситься и запоминаться;

2. узнаваться во всех языках;

3. позитивно восприниматься;

4. вызывать положительные эмоции;

5. выражать выгоду и преимущество продукта.

Правильно подобранное имя несет в себе семантический потенциал и способствует усилению его коммуникативной значимости.

Считается, что при покупки товаров, решения у потребителя возникают на бессознательном уровне. Поэтому воздействие продукта нейминга происходит на бессознательном уровне. В процессе нейминга, в название бренда вкладываются эмоциональные и положительные образы, поскольку они оставляют след в сознании человека. Эмоциональный образ абстрактный семантический код, имеет метафорическую природу, воспроизводит приятные ощущения при напоминании о нем. Другой способ - нейролингвистическое программирование, которые повышают степень воздействия бренда на подсознание. Речевые пресуппозиции позволяют строить предложения таким образом, чтобы смещать фокус внимания на необходимые детали продукта. Мыслевирус - некая вирусная информация в памяти людей и автономно распространяется между ними. Мыслевирус содержит в себе некий стимул, который мотивирует его распространение. 
Смысл сообщения, вложенный в имя бренда, должен совпадать с замыслом производителя и владельцем бренда. Технология пресуппозиция позволяет выделять детали, которые воспринимаются как само собой разумеющееся. Восприятие бренда происходит субъективно, например «Хорошие хозяйки выбирают «Tide»», в данном высказывании факты связаны логической связью. которые домысливаются покупателем: «Почему хорошие хозяйки?» логически домысливается покупателем «Потому что покупают «Tide»». Данное сообщение передает причинно-следственную связь на бессознательном уровне.

Несмотря на то, что восприятия образа бренд-нейма индивидуально, тем не менее существуют общие критерии, способные вызвать удовлетворенность потребителя. Главная цель разработчиков бренда - воздействие на реципиента. Существуют множество способов бренд-нейминга: ассоциативные названия, подбор известных слов, иностранные заимствования, неологизмы. Образование неологизмов с использованием фоносемантических методик занимает особое место в области нейминга. Слова-неологизмы, как правило не имеют лексического значения, например такие имена как «Sony», «Audi». Семантический прием при разработки имени основывается на уникальных особенностях бренда, его основных характеристиках и связанных с ним ассоциациях. Фонетический прием образуются на основании звукоподражания, когда делается акцент на звучании слова. Примером такого названия может служить название «Kodak», которое репрезентирует щелчок фотокамеры во время съемки. Производители продукта и рекламщики учитывают сферу распространения товара, поэтому имя транслирует значение, которое будет легко восприниматься в той или иной стране. Также большое значение имеет алфавит, который будет передавать звучание имени. Таким образом, рождение имени происходит на стыке фонетики (в контексте выражения), семантики (в контексте содержания), психологии (в контексте восприятия).

По способу образования выделяются бренды: аббревиатуры («Adidas», «Lego», «Росгосстрах»), акронимы («BMW», «ВТБ», «МТС», «ГУМ»), составные слова («Greenfield», «PayPal», «YouTube», «Volkswagen»), гибриды («Nesquick», 
«Instagram», «Фруктайм»), сокращения («Google», «Nivea», «Pepsi»), имена собственные («Skoda», «Быстров», «Аленка», «Hilton»), топонимы («Ессунтуки», «Вологодское», «Шатура»).

В последнее время в создании коммерческого наименования, на смену аббревиатур и акронимам пришло использование лексических средств, тропов: метафор («Красное\&Белое», «Маленькая фея»), метонимий («Растишка», «Деревенское»), гипербол («Вкусландия», «Детский мир»), эпитетов («Золотая бочка», «Мечта хозяйки»), перифразов («Все для охоты», «Up \& Go») и т.д.

Выделяются названия по характеру выбранных приемов: звуковые ассоциации («Yahoo!», «Whiskas», «Zippo», «Лисма»), мимикрии («Pizza», «Twix», «Absolut», «Nesquik»), аллитирация («Chupa Chups», «KitKat», «Тic-Тас», «Сам самыч»), рифма и анафора («СосаCola», «Pickwick», «Tutti-Frutti»), иностранные заимствования («Oggi», «Гранд»), антропонимы(«Mercedes»), «Калашников»)).

Таким образом, бренд в лингвистике - это набор реальных и потенциальных мнений, который реализуются в определенном продукте, а его имя несет в себе функциональную нагрузку. Имя бренда является важнейшей его составляющей, кратко выражкает его суг, передает определенный эмоционалыный смысл. В долгосрочной перспективе образует стратегический потенциал бренда. Несомненным остается факт, что главная функция бренда - это поддержание образа его высокого качества. Репугация бренда влияет на его конкурентоспособность нарынке.

\section{ЛИТЕРАТУРА}

1. Боровикова Н. В. Бренд как культурный феномен// Иностранные языки в высшейшколе №3 (46). 2018. С.46-53

2. Изотова Е.И., Сизова В.В. Лингвомаркетинговые тенденции развития нейминга/Вестник Тверского государственного технического университета. серия: науки об обществе и гуманитарные науки. №3. Тверь. 2018. С. 71-75.

3. Кожанова В.А. Лингвистические основы наименования брендов (на примере английского и русского языка): автореф.дисс.на соиск.уч.степен.канд.филол.наук. Краснодар, 2007.-20c.

4. Латыпова Ю.А. Раянова Е.Р. Понятие лингвоимиджелогии в современной науке//«Актуальные проблемы теоретической и прикладной филологии〉 (апрель 2021 г.): мат-лы ХХ междунар. научн. конф., РИНЦБашГУ, 2021.

5. Сасина С.А., Брычева М.М. Лингвистические аспекты нейминга (на материале англоязычных бредов)/Вестник «АГУ». Выпуск 2.(197). 2017. С.113-118.

(C) ЛатьповаЮ.А.,2021 г. 